\title{
Characteristics of Anti-SARS-CoV-2 Antibodies in Recovered COVID-19 Subjects
}

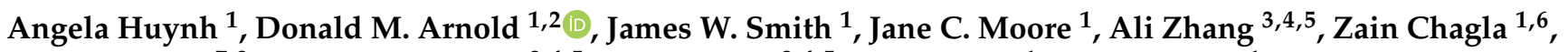 \\ Bart J. Harvey ${ }^{7,8}$, Hannah D. Stacey ${ }^{3,4,5}$, Jann C. Ang ${ }^{3,4,5}$, Rumi Clare ${ }^{1}$, Nikola Ivetic ${ }^{1}$, Vasudhevan T. Chetty ${ }^{9,10}$,
} Dawn M. E. Bowdish ${ }^{1,3,4}$, Matthew S. Miller ${ }^{3,4,5} \oplus^{\text {, John G. Kelton }}{ }^{1,2}$ and Ishac Nazy ${ }^{1,2, *}$

1 Department of Medicine, Michael G. DeGroote School of Medicine, McMaster University, Hamilton, ON L8N 3Z5, Canada; huynha8@mcmaster.ca (A.H.); arnold@mcmaster.ca (D.M.A.); smithjw@mcmaster.ca (J.W.S.); moorej@mcmaster.ca (J.C.M.); chaglaz@mcmaster.ca (Z.C.); rclare@mcmaster.ca (R.C.); iveticnj@mcmaster.ca (N.I.); bowdish@mcmaster.ca (D.M.E.B.); keltonj@mcmaster.ca (J.G.K.)

2 McMaster Centre for Transfusion Research, McMaster University, Hamilton, ON L8N 3Z5, Canada

3 Michael G. DeGroote Institute for Infectious Disease Research, McMaster University, Hamilton, ON L8S 4K1, Canada; zhanga19@mcmaster.ca (A.Z.); staceyhd@mcmaster.ca (H.D.S.); angjc2@mcmaster.ca (J.C.A.); mmiller@mcmaster.ca (M.S.M.)

4 McMaster Immunology Research Centre, McMaster University, Hamilton, ON L8S 4K1, Canada

5 Department of Biochemistry and Biomedical Sciences, McMaster University, Hamilton, ON L8S 4K1, Canada

6 Division of Infectious Diseases, Department of Medicine, McMaster University, Hamilton, ON L8V 1C3, Canada

7 Hamilton Public Health Services, Hamilton, ON L8P 4Y5, Canada; bart.harvey@hamilton.ca

8 Dalla Lana School of Public Health, University of Toronto, Toronto, ON M5T 3M7, Canada

check for updates

Citation: Huynh, A.; Arnold, D.M.; Smith, J.W.; Moore, J.C.; Zhang, A.; Chagla, Z.; Harvey, B.J.; Stacey, H.D.; Ang, J.C.; Clare, R.; et al.

Characteristics of Anti-SARS-CoV-2 Antibodies in Recovered COVID-19 Subjects. Viruses 2021, 13, 697. https://doi.org/10.3390/v13040697

Academic Editor:

Luis Martinez-Sobrido

Received: 6 March 2021

Accepted: 10 April 2021

Published: 16 April 2021

Publisher's Note: MDPI stays neutral with regard to jurisdictional claims in published maps and institutional affiliations.

Copyright: (c) 2021 by the authors. Licensee MDPI, Basel, Switzerland. This article is an open access article distributed under the terms and conditions of the Creative Commons Attribution (CC BY) license (https:// creativecommons.org/licenses/by/ $4.0 /)$.
9 Hamilton Regional Laboratory Medicine Program, Hamilton Health Sciences, Hamilton, ON L8N 4A6, Canada; chetty@hhsc.ca

10 Department of Pathology and Molecular Medicine, McMaster University, Hamilton, ON L8S 4L8, Canada

* Correspondence: nazii@mcmaster.ca; Tel.: +(905)-525-9140-x20242

\begin{abstract}
Coronavirus Disease 2019 (COVID-19) is a global pandemic caused by the novel severe acute respiratory syndrome coronavirus 2 (SARS-CoV-2). While detection of SARS-CoV-2 by polymerase chain reaction with reverse transcription (RT-PCR) is currently used to diagnose acute COVID-19 infection, serological assays are needed to study the humoral immune response to SARSCoV-2. Anti-SARS-CoV-2 immunoglobulin (Ig)G/A/M antibodies against spike (S) protein and its receptor-binding domain (RBD) were characterized in recovered subjects who were RT-PCR-positive $(n=153)$ and RT-PCR-negative $(n=55)$ using an enzyme-linked immunosorbent assay (ELISA). These antibodies were also further assessed for their ability to neutralize live SARS-CoV-2 virus. Anti-SARSCoV-2 antibodies were detected in $90.9 \%$ of resolved subjects up to 180 days post-symptom onset. Anti-S protein and anti-RBD IgG titers correlated $(r=0.5157$ and $r=0.6010$, respectively) with viral neutralization. Of the RT-PCR-positive subjects, 22 (14.3\%) did not have anti-SARS-CoV-2 antibodies; and of those, 17 had RT-PCR cycle threshold $(\mathrm{Ct})$ values $>27$. These high $\mathrm{Ct}$ values raise the possibility that these indeterminate results are from individuals who were not infected or had mild infection that failed to elicit an antibody response. This study highlights the importance of serological surveys to determine population-level immunity based on infection numbers as determined by RT-PCR.
\end{abstract}

Keywords: SARS-CoV-2; COVID-19; antibody; serology

\section{Introduction}

Coronavirus disease 2019 (COVID-19) is caused by the novel severe acute respiratory syndrome coronavirus 2 (SARS-CoV-2) [1]. Asymptomatic and pre-symptomatic virus transmission is one of the biggest challenges with this global pandemic [2]. It is estimated up to $80 \%$ of people infected with COVID-19 have none or mild symptoms and asymptomatic transmission accounts for half of all COVID-19 infections [3-5]. Approximately 
$20 \%$ of symptomatic infections are severe, disproportionately impacting the elderly and patients with underlying health conditions $[6,7]$.

Laboratory diagnosis of COVID-19 is made using polymerase chain reaction with reverse transcription (RT-PCR) to detect viral mRNA from nasal or throat swabs [8-11]. Viral RNA is detectable as early as the first day of symptom onset and peaks within the first week of symptom onset [9]. The SARS-CoV-2 spike (S) protein, specifically the receptor-binding domain (RBD), facilitates viral entry into the cell via the angiotensinconverting enzyme-2 (ACE2) receptor on host cells [12-15]. Most people with a confirmed RT-PCR diagnosis of SARS-CoV-2 infection develop immunoglobulin (Ig)G, IgA, and IgM antibodies against $S$ protein within 1-2 weeks of symptom onset and continue to circulate after initial viral clearance [16-21].

Serological studies have shown IgG antibodies to SARS-CoV-2 S protein and RBD are detected in the circulation of greater than $90 \%$ of infected subjects by $10-11$ days post-symptom onset $[16,18,20,22]$. Virus-specific neutralizing antibodies, either induced through infection or vaccination, can block viral infection [23]. Although antibodies may be generated against multiple domains within the $S$ protein, most neutralizing antibodies and highly potent monoclonal antibodies target the RBD [15,24,25]. In this report, we profile the IgG, IgA, and IgM responses to the SARS-CoV-2 S protein and RBD in a cross-sectional serological study involving resolved COVID-19 infection. We also compared antibody levels with viral neutralization and RT-PCR results.

\section{Materials and Methods}

\subsection{Study Design}

Subjects who recovered from COVID-19 infection were identified by treating physicians, public health officials and through hospital discharge databases that included hospitals in Hamilton, Ontario, Canada (Hamilton General Hospital, Juravinski Hospital, McMaster University Medical Centre, and St. Joseph's Healthcare). The study inclusion criteria were $>18$ years of age, either testing positive or negative for COVID-19 in the RT-PCR, with no exclusion criteria.

Participants with RT-PCR-positive results for SARS-CoV-2 and had since recovered (resolved RT-PCR-positive, $n=153$ ), and subjects who experienced symptoms but tested negative by RT-PCR (RT-PCR-negative, $n=55$ ) were included. Participants were interviewed by phone and self-reported their age, sex, symptom onset date, and RT-PCR test date and result. Pre-COVID-19 control samples were selected from healthy donors $(n=37)$, from the ITP Registry biobank and from the McMaster Platelet Immunology Laboratory drawn prior to November 2019 (pre-COVID-19, $n=483$ ) before documented local community transmission of SARS-CoV-2. Serum was collected by venipuncture and cryopreserved until use. This study was approved by the Hamilton Integrated Research Ethics Board (HiREB) and written informed consent was obtained from all participants.

\subsection{Production of Recombinant SARS-CoV-2 S Protein and RBD}

A detailed protocol outlining protein production can be found in a study by Stadlbauer et al. [26] and is outlined in the supplemental methods.

\subsection{Measuring SARS-CoV-2 Antibodies}

Microtiter well plates (384 wells, Nunc Maxisorp, Rochester, NY, USA) were coated with $25 \mu \mathrm{L} /$ well of S protein $(5 \mu \mathrm{g} / \mathrm{mL})$ or RBD $(2 \mu \mathrm{g} / \mathrm{mL})$ suspended in $50 \mathrm{mM}$ carbonatebicarbonate buffer ( $\mathrm{pH}$ 9.6). The plates were then blocked with $100 \mu \mathrm{L} /$ well of $3 \%$ skim milk prepared in phosphate buffered saline (PBS) with $0.05 \%$ Tween 20 at room temperature for $2 \mathrm{~h}$. The blocking solution was removed, and diluted serum samples (1/100 prepared in $1 \%$ skim milk in PBS $/ 0.05 \%$ Tween 20 ) in technical duplicates were added to the plates and incubated for $1 \mathrm{hr}$ at room temperature. The plates were washed twice with PBS $/ 0.05 \%$ Tween 20 and thrice with PBS. Bound human antibodies (IgG, IgA, or IgM) were detected with $25 \mu \mathrm{L} /$ well of alkaline phosphatase conjugated goat anti-human IgG $(\gamma$ - 
chain-specific, 1/2000, Jackson ImmunoResearch Laboratories, Inc., Westgrove, PA, USA), goat anti-human IgA ( $\alpha$-chain-specific; 1/500, Jackson ImmunoResearch Laboratories, Inc., Westgrove, PA, USA) antibody, or goat anti-human IgM ( $\mu$-chain-specific; $1 / 1000$, Jackson ImmunoResearch Laboratories, Inc., Westgrove, PA, USA) antibody prepared in PBS $/ 0.05 \%$ Tween 20 with $1 \%$ skim milk. Plates were washed as before and followed with the addition of $50 \mu \mathrm{L}$ substrate (4-nitrophenylphosphate disodium salt hexahydrate in diethanolamine (MilliporeSigma, St. Louis, MO, USA). The optical density (OD) was read at $405 \mathrm{~nm}$ and $490 \mathrm{~nm}$ (as a reference) using a BioTek 800TS microplate reader (BioTek, Winooski, VT, USA). The assay cut-off was determined as the mean and 3 standard deviations (SD) of the pre-COVID-19 control population. Data are shown as a ratio of observed OD to the determined assay cut-off OD. OD ratio values above 1 ratio were considered positive in the SARS-CoV-2 ELISA. Results for optimization of antigens, serum concentrations for the ELISA and its comparisons to commercially available assays can be found in the supplemental data (Table S1).

\subsection{PCR Cycle Threshold (Ct) Values of Resolved COVID-19 Samples}

RT-PCR Ct values were retrieved from a subset of resolved subjects' original test date RT-PCR $(n=54)$. A detailed protocol of the in-house RT-PCR run by the Hamilton Regional Laboratory Medicine Program virology lab is outlined in the Supplemental methods.

\subsection{Detecting Neutralizing Antibodies for SARS-CoV-2}

Vero E6 cells (ATCC CRL-1586) were seeded at a density of $2.5 \times 10^{4}$ cells per well in opaque 96 well flat-bottom plates (Costar) in complete DMEM (supplemented with $10 \%$ FBS, 1\% L-glutamine, $100 \mathrm{U} / \mathrm{mL}$ penicillin-streptomycin). Twenty-four hours later, serum (resolved and RT-PCR-negative subjects) was inactivated by incubating at $56{ }^{\circ} \mathrm{C}$ for $30 \mathrm{~min}$, then diluted 1:10 in low serum DMEM (supplemented with 2\% FBS, 1\% Lglutamine, $100 \mathrm{U} / \mathrm{mL}$ penicillin-streptomycin), followed by a 1:2 dilution series in 96 well U-bottom plates resulting in a final volume of $55 \mu \mathrm{L}$ diluted serum per well. An equal volume of SARS-CoV-2/SB3-TYAGNC consisting of 330 PFU per well was then added to the diluted serum and the serum-virus mixture was incubated at $37^{\circ} \mathrm{C}$ for $1 \mathrm{~h}$. Next, the Vero E6 culture media was then replaced with $100 \mu \mathrm{L}$ of the serum-virus mixture and was incubated at $37^{\circ} \mathrm{C}$ for $72 \mathrm{~h}$. The plates were read by removing $50 \mu \mathrm{L}$ of culture supernatant and adding $50 \mu \mathrm{L}$ of CellTiter-Glo 2.0 Reagent (Promega, G9243) to each well. The plates were then shaken at $282 \mathrm{cpm}$ at $3 \mathrm{~mm}$ diameter for $2 \mathrm{~min}$, incubated for $5 \mathrm{~min}$ at room temperature and luminescence was read using a BioTek Synergy H1 microplate reader with a gain of 135 and an integration time of $1 \mathrm{~s}$. Results are expressed as geometric microneutralization titers at 50\% (MNT50).

\subsection{Statistical Analyses}

Descriptive statistics were used to summarize the IgG, IgA, and IgM binding to $S$ protein and $\mathrm{RBD}$ as measured by mean $\mathrm{OD} \pm \mathrm{SD}$ across antigen and technical replicates. Differences between data were tested for statistical significance using the paired or unpaired $t$-test and the Mann-Whitney test. $P$-values are reported as 2 -tailed and $p$-values less than 0.05 were considered significant. Correlations were calculated using standard Pearson correlation. All statistical analyses were conducted using GraphPad Prism (version 9.1.0, GraphPad Software, San Diego, CA, USA).

\section{Results}

\subsection{Study Demographics}

Resolved (RT-PCR-positive, $n=153$ ) samples were collected between 7 and 211 days post-symptom onset. Median age of the resolved RT-PCR-positive subjects was 49 years (range: $18-82)$ and 95 subjects (62.1\%) were female. COVID-19 negative subjects (RTPCR-negative, $n=55$ ) samples were collected between 7 and 246 days post-symptoms (Table 1). The median age of the RT-PCR-negative subjects was 49 years (range: 20-89) and 
$39(70.9 \%)$ were female (Table 1$)$. Eleven (7.2\%) of the RT-PCR-positive resolved subjects and $18(32.7 \%)$ of the RT-PCR-negative subjects were asymptomatic before testing.

Table 1. Clinical Characteristics of Study Participants.

\begin{tabular}{|c|c|c|c|}
\hline & $\begin{array}{l}\text { Pre-COVID-19 } \\
\text { Controls } \\
(n=520)\end{array}$ & $\begin{array}{c}\text { Resolved COVID-19 } \\
\text { Subjects } \\
(n=153)\end{array}$ & $\begin{array}{c}\text { RT-PCR-Negative } \\
\text { Subjects } \\
(n=55)\end{array}$ \\
\hline Ages (years) & - & $\begin{array}{c}18 \text { to } 82 \\
\text { (median }=49)\end{array}$ & $\begin{array}{c}20 \text { to } 89 \\
(\text { median }=49)\end{array}$ \\
\hline \multicolumn{4}{|l|}{ Sex } \\
\hline Male (\%) & - & $58(37.9)$ & $16(29.1)$ \\
\hline Female $(\%)$ & - & $95(62.1)$ & $39(70.9)$ \\
\hline \multicolumn{4}{|l|}{ Hospitalization Status } \\
\hline Never hospitalized (\%) & - & $145(94.8)$ & $55(100)$ \\
\hline Hospitalized (\%) & - & $8(5.2)$ & 0 \\
\hline $\begin{array}{c}\text { Sample Collection } \\
\text { Dates }\end{array}$ & - & \multicolumn{2}{|c|}{ May 2020-November 2020} \\
\hline \multicolumn{4}{|l|}{$\begin{array}{l}\text { SARS-CoV-2 RT-PCR } \\
\text { positivity }\end{array}$} \\
\hline Positive & - & 153 & 0 \\
\hline Negative & - & 0 & 55 \\
\hline \multicolumn{4}{|l|}{ Presence of symptoms } \\
\hline Symptomatic (\%) & - & $142(92.8)$ & $37(67.3)$ \\
\hline Asymptomatic (\%) & - & $11(7.2)$ & $18(32.7)$ \\
\hline $\begin{array}{l}\text { Days post-symptom } \\
\text { onset at collection (days) }\end{array}$ & - & $\begin{array}{c}19-227 \\
(\text { median }=130.5)\end{array}$ & $\begin{array}{c}7-260 \\
\text { (median }=141.5)\end{array}$ \\
\hline
\end{tabular}

\subsection{Detecting SARS-CoV-2 Antibodies in Resolved COVID-19 Subjects}

To study the antibody response to SARS-CoV-2, we tested for IgG, IgA, and IgM antibodies to the $S$ protein and RBD in pre-COVID-19 controls $(n=520)$, resolved COVID-19 subjects $(n=153)$, and RT-PCR-negative subjects $(n=55)$. Pre-COVID-19 controls $(n=520)$ were used to determine the background reactivity to the $S$ protein and RBD using samples from individuals drawn pre-November 2019. The cut-off was determined as the mean plus 3 SD of the OD readings in the pre-COVID-19 control population. Most pre-COVID19 controls had only background reactivity for both the full-length $S$ protein and RBD (IgG $=98.9 \%, n=514 / 520$, and $98.5 \%, n=512 / 520$ below established cut-off, respectively, Figure S5A,B). Each antigen and antibody class had a few pre-COVID-19 controls that tested positive for antibodies based on the determined cut-off. The majority of pre-COVID19 controls that tested positive within the groups had IgM against both $S$ protein and RBD, $1.5 \%(n=8 / 520$ testing antibody-positive, Figure S5E) and 2.1\% $(n=11 / 520$ antibodypositive, Figure S5F), respectively. Some control samples were positive in the $S$ proteinand RBD-specific IgA assays: 1.3\% $(n=7 / 520$ antibody-positive, Figure S5C) and 1.0\% $(n=5 / 520$ antibody-positive, Figure S5D), respectively. Antigen concentrations of S protein and RBD and serum dilutions were optimized by testing known COVID-19-positive and pre-COVID-19 samples (see supplemental data, Figure S1).

Of the 153 resolved COVID-19 subjects tested, 131 (85.6\%) tested positive for antibodies against SARS-CoV-2 (IgG, IgA, or IgM antibodies against the S protein or RBD, Table 2) and $22(14.4 \%)$ did not have detectable antibodies against SARS-CoV-2. Of the 55 RT-PCRnegative subjects, three had reactivity to the SARS-CoV-2 antigens (5.5\%, Table 2). Most resolved subjects tested positive for anti-S protein and anti-RBD IgG $(n=130 / 153$ testing positive $(85.0 \%)$ and $n=119 / 153$ testing positive $(77.8 \%)$, respectively, Figure S5A,B). In addition, some of the same resolved subjects also tested positive for anti-S protein IgA (60.1\%, 92/153 antibody-positive, Figure S5C), anti-S protein IgM (35.3\%, 54/153 antibody- 
positive, Figure S5E), and anti-RBD IgA (24.2\%, 37/153 antibody-positive, Figure S5D) and $\operatorname{IgM}(19.6 \%, 30 / 153$ antibody-positive, Figure S5F).

Table 2. Cross-sectional analysis of RT-PCR and SARS-CoV-2 Antibody Testing.

\begin{tabular}{lcc}
\hline & $\begin{array}{c}\text { RT-PCR-Positive } \\
\text { (Resolved, } \boldsymbol{n}=\mathbf{1 5 3})\end{array}$ & $\begin{array}{c}\text { RT-PCR-Negative } \\
(\boldsymbol{n}=\mathbf{5 5})\end{array}$ \\
\hline \multirow{2}{*}{ SARS-CoV-2 Antibody positive (\%) } & $131 / 153$ & $3 / 55$ \\
& $(85.6)$ & $(5.5)$ \\
\hline \multirow{2}{*}{ SARS-CoV-2 Antibody negative (\%) } & $22 / 153$ & $52 / 55$ \\
& $(14.4)$ & $(94.5)$ \\
\hline
\end{tabular}

\subsection{High Ct Counts Found in Resolved Subjects Who Were SARS-CoV-2 Antibody-Negative}

To further understand RT-PCR-positive COVID-19 subjects that tested negative for anti-SARS-CoV-2 antibodies, 22/153 (14.4\%) resolved subjects were further investigated. The Ct values from the initial RT-PCR test were obtained for 54/153 (35.3\%) of the resolved participants, including 18/22 (81.8\%) who were RT-PCR-positive but antibodynegative. The $\mathrm{Ct}$ values for the RT-PCR-positive/antibody-negative subjects $(n=18)$ ranged from 16.00 to 37.38 , with a mean of $32.29 \pm 4.647$, whereas, the mean of the subjects who were RT-PCR-positive/antibody-positive was $22.92 \pm 5.177$ (range = 14.99-34.94, $n=36$, Figure $1 \mathrm{~A}, \mathrm{~B})$. Sera from 13 of $18(72.2 \%)$ resolved subjects who tested RT-PCRpositive/antibody-negative were collected within 60 days after initial RT-PCR test, within the reported optimal time for anti-SARS-CoV-2 antibodies (Figure 1C) [18,20,21,27].
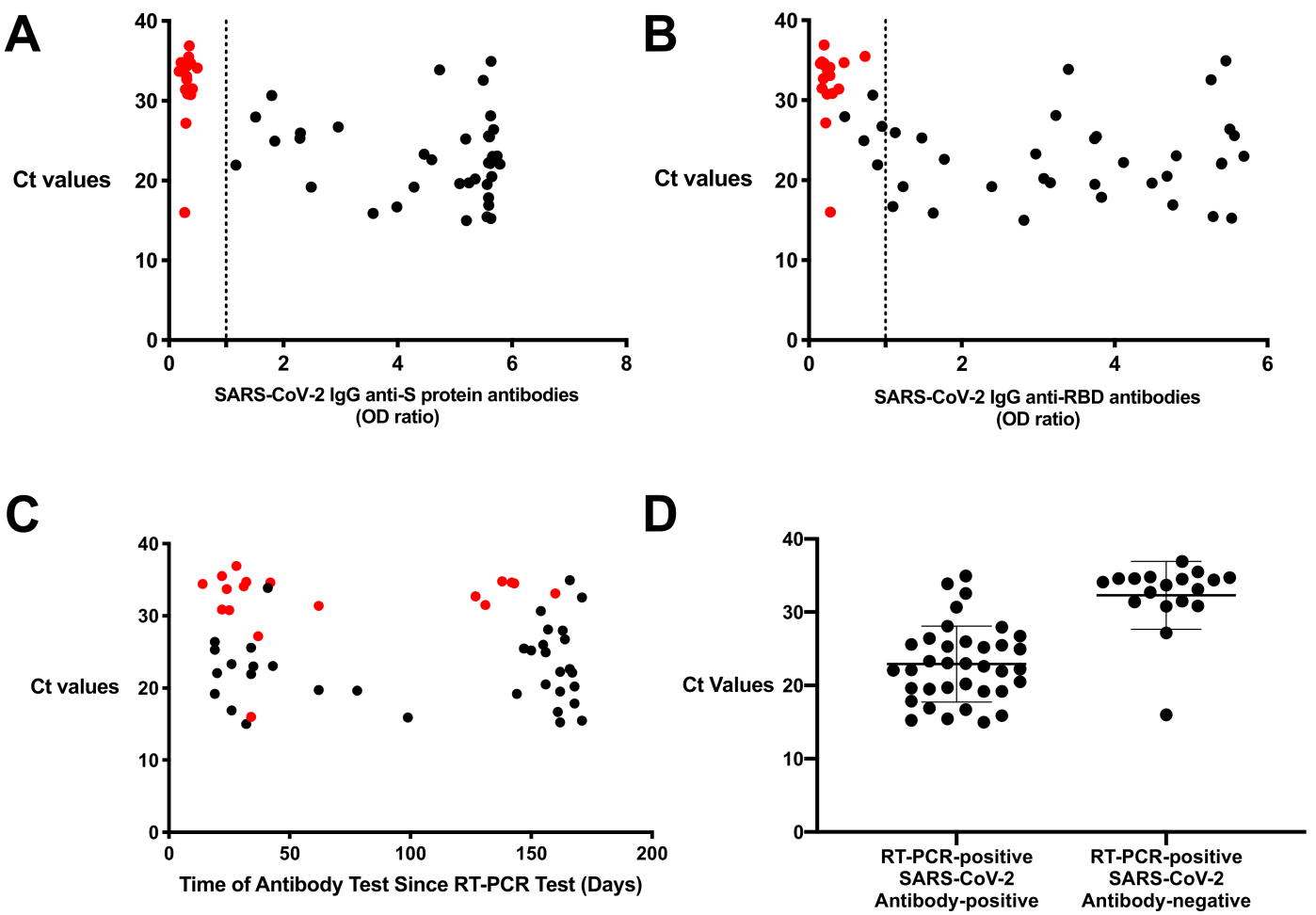

Figure 1. Ct values were variable in resolved subjects who test SARS-CoV-2 antibody negative or positive. Ct values of a subset of resolved subjects $(n=54)$ were compared to their corresponding SARS-CoV-2 (A) anti-S protein IgG and (B) anti- receptor-binding domain (RBD) IgG. (C) Ct values were then compared to the subjects' respective time since initial RT-PCR test. (D) Ct values for RT-PCR-positive in antibody-positive and antibody-negative were compared. Values are shown as a ratio of observed optical density to the determined assay cut-off optical density or time since RT-PCR test until blood donation compared to absolute Ct values. Red circles indicate resolved samples who were RT-PCR-positive/antibody-negative. 
During assay validation, 14 resolved subjects (9 antibody-positive and 5 antibodynegative) were tested in the commercially available EUROIMMUN Anti-SARS-CoV-2 ELISA and the Ortho Clinical Diagnostics COVID-19 IgG Antibody Test. Three of the 14 subjects sent for validation testing were RT-PCR-positive/antibody-negative and had high $\mathrm{Ct}$ value samples and were confirmed to be negative for SARS-CoV-2 antibodies in the commercial reference assays (Supplemental data Table S1).

\subsection{Persistence of Anti-S Protein and Anti-RBD Antibodies in Resolved Subjects}

IgG antibodies against $S$ protein and RBD were also tested in samples collected $>120$ days from symptom onset (Figure 2A). Asymptomatic subjects were collected between 27 and 160 days after their RT-PCR test. Anti-S protein IgG was found in all resolved participants collected between 60 and 120 days (23/153 or $15.0 \%$ of resolved subjects). However, at the next time interval of 120-180 days following symptom onset, only 55/60 $(91.7 \%)$ of resolved patient samples had anti-S protein IgG detected, indicating a decline in antibody production in some individuals. Of the resolved subjects tested $>180$ days of symptom onset $(n=11), 90.9 \%$ had an anti-S protein IgG antibody. In addition, IgG levels against RBD demonstrated a $14.8 \%$ decrease in subjects who were antibody-positive between 120 and 180 days when compared to the groups before 120 days, and a 30\% decrease in subjects with antibody after 180 days (Figure 2A). In contrast, IgA and IgM to both antigens were much less sustained (IgA-Figure 2B, IgM-Figure 2C). After reaching a maximum titer in the 0-60 days interval, there was a clear and continuous decline throughout the time series such that after 180 days, the anti-S protein and anti-RBD IgA levels in subject groups declined by $30 \%$ and $80 \%$, respectively, while IgM levels for both antigens declined by $90 \%$ (IgA-Figure 2B, IgM-Figure 2C).

\subsection{Investigation of Neutralizing SARS-CoV-2 Antibodies}

Neutralization potency was measured using a microneutralization assay with live SARS-CoV-2 virus. In all resolved subjects, the presence of high titers of anti-S protein and anti-RBD IgG moderately correlated with higher titers of neutralizing antibodies (Figure 3A,B, $r=0.5157, p<0.0001$ anti-S protein IgG and $r=0.601, p<0.0001$ anti-RBD IgG). Weaker correlations were found between neutralizing antibody titers and anti-S protein $\operatorname{IgA}(r=0.4507), \operatorname{IgM}(r=0.4443)$, and anti-RBD $\operatorname{IgA}(r=0.3055), \operatorname{IgM}(r=0.3365)$. Geometric microneutralization titers at 50\% (MNT50) ranged from below detection limit $($ MNT50 $=5)$ to MNT50 $=1280$. Resolved subjects who were only antibody-positive for anti-S protein IgG but not antibody-positive for anti-RBD IgG antibodies $(n=11)$ either had lower neutralizing antibody levels (mean MNT50 $=19.5$, range: 5-80) or were undetectable. No temporal trends were observed based on this cross-sectional study of resolved subjects, however neutralizing antibodies in resolved subjects were detected as far as 180 days postsymptom onset (Figure 3C). After 180 days, 3/11 (27.3\%) of subjects tested for neutralizing antibodies had a level above MNT50 $=160$. All hospitalized subjects produced neutralizing antibodies at titers above the suggested U.S. Food and Drug Administration (FDA) level (Table 3). 
A

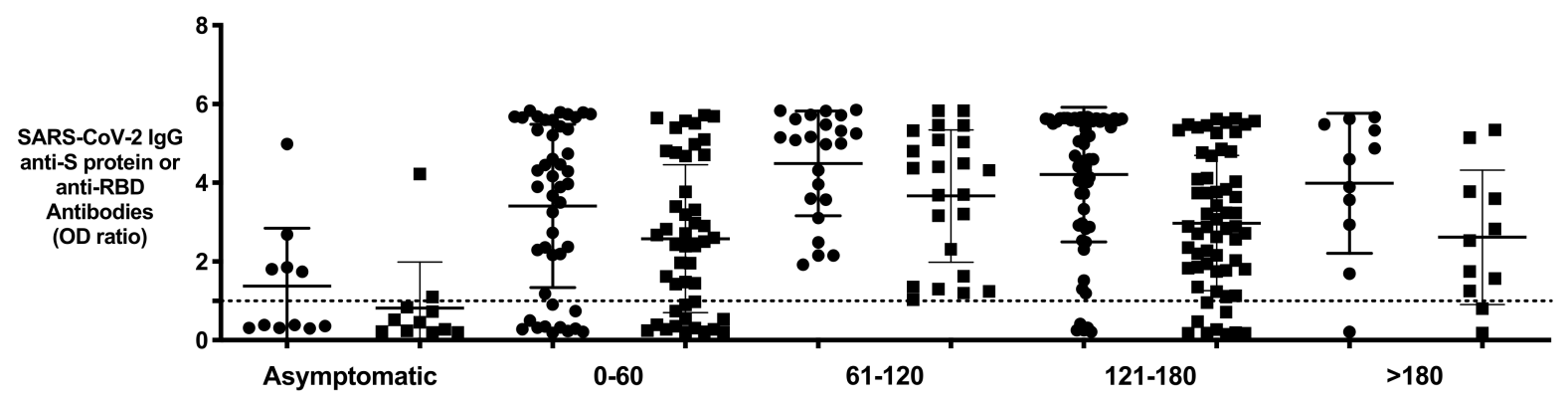

B

Days post-symptom onset

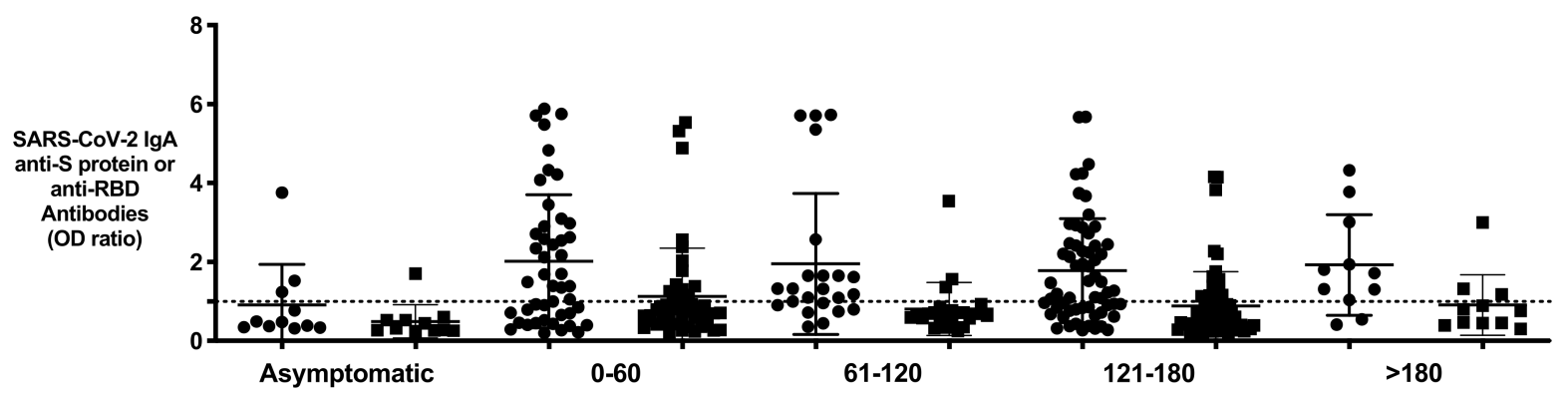

Days post-symptom onset

C

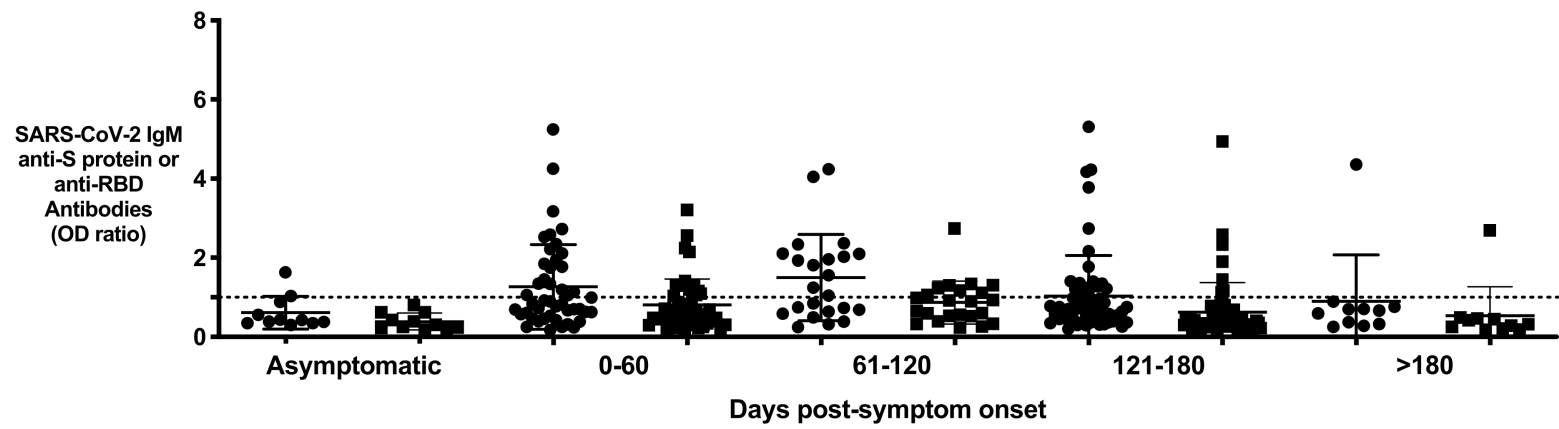

- anti-S protein

- anti-RBD

Figure 2. Persistence of SARS-CoV-2 antibodies in resolved subjects based on time of blood collection post-symptom onset. Resolved subjects $(n=153)$ were grouped based on days post-symptom onset showing levels of $(\mathbf{A})$ anti-S protein and anti-RBD IgG, (B) IgA, and (C) IgM displayed as dot plots. Days post-symptom onset were binned in 60-day increments and are compared to asymptomatic resolved subjects. Asymptomatic subjects were collected between 27 and 160 days after their RT-PCR test. Circles represent anti-S protein antibodies and squares represent anti-RBD antibodies. Anti-S protein IgG was found in all resolved participants collected between 60 and 120 days (23 of 153 total resolved subjects). In the resolved patients collected between 120 and 180 days from symptom onset, there was a decrease in the percentage of antibody-positive samples when compared to the previous time bin (55 of 60 samples, 91.7\%). 

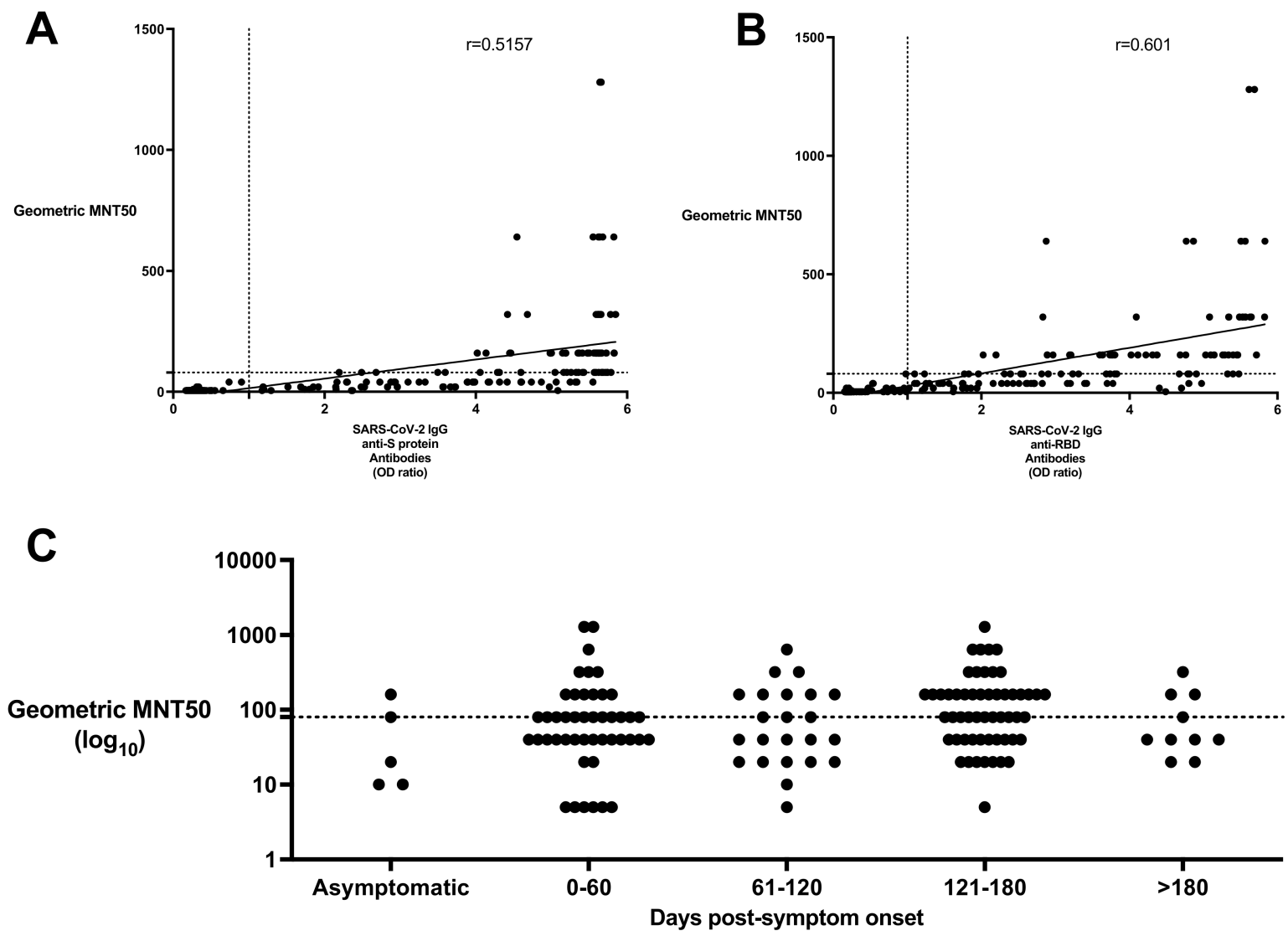

Figure 3. Neutralizing SARS-CoV-2 IgG, IgA, and IgM antibodies against S protein and RBD were found in variable levels in resolved and RT-PCR-negative study participants. Neutralizing SARS-CoV-2 antibody titers from resolved subjects ( $n=153$ ) were measured in the microneutralization assay and compared to (A) anti-S protein and (B) anti-RBD IgG antibody levels as measured in the SARS-CoV-2 ELISA. Neutralizing antibody titers are expressed as geometric MNT50 values (y-axis). ELISA values are shown as a ratio of observed optical density to the determined assay cut-off optical density (x-axis). (C) Neutralizing SARS-CoV-2 antibody titers from resolved subjects $(n=153)$ were measured in the microneutralization assay and were compared to their days since symptom onset. $X$-axis is expressed in $\log _{10}$. Values above 1 ratio are considered positive in the SARS-CoV-2 ELISA.

Table 3. Level of neutralization in asymptomatic, non-hospitalized and hospitalized resolved COVID19 subjects.

\begin{tabular}{cccc}
\hline Level of Neutralization & $\begin{array}{c}\text { Asymptomatic } \\
(\boldsymbol{n}=\mathbf{1 1})\end{array}$ & $\begin{array}{c}\text { Non-Hospitalized } \\
(\boldsymbol{n}=\mathbf{1 3 4})\end{array}$ & $\begin{array}{c}\text { Hospitalized } \\
(\boldsymbol{n}=\mathbf{8})\end{array}$ \\
\hline Undetectable & $\begin{array}{c}6 / 11 \\
(54.5 \%)\end{array}$ & $\begin{array}{c}20 / 134 \\
(14.9 \%)\end{array}$ & 0 \\
\hline \multirow{2}{*}{ Below Suggested FDA Level } & $3 / 11$ & $50 / 134$ & 0 \\
\hline \multirow{2}{*}{ Above Suggested FDA Level } & $(27.3 \%)$ & $(37.3 \%)$ & $8 / 8$ \\
\hline
\end{tabular}

3.6. SARS-CoV-2 Antibody Profile of Asymptomatic, Non-Hospitalized, and Hospitalized Resolved Subjects

Of the 153 resolved subjects tested, eight (5.2\%) were hospitalized for SARS-CoV-2 infection and were positive for anti-SARS-CoV-2 antibodies. All hospitalized subjects had detectable anti-RBD and anti-S protein IgG, and anti-S protein IgA antibodies in their serum (Figure 4A,B). The levels of anti-S protein and anti-RBD IgG (mean OD $_{405 \mathrm{~nm}}$ ratio) in resolved subjects who were hospitalized were significantly higher than the asymptomatic 
(anti-S protein IgG; $5.667 \pm 0.065$ vs. $1.372 \pm 1.474, p<0.001$; anti-RBD IgG $5.240 \pm 0.8483$ vs. $0.8164 \pm 1.168, p<0.001$ ) and non-hospitalized resolved population (anti-S protein IgG; $5.667 \pm 0.065$ vs. $3.836 \pm 1.831, p<0.05$; anti-RBD IgG $5.240 \pm 0.8483$ vs. $2.758 \pm 1.730$, $p<0.001)$. All other antigen and antibody classes were not significantly different between asymptomatic, non-hospitalized, and hospitalized resolved subjects. When compared to resolved hospitalized subjects (range: 3.209-5.831), there was a larger spread in antibody levels in the non-hospitalized population (range: 0.1508-5.828; Figure 4).
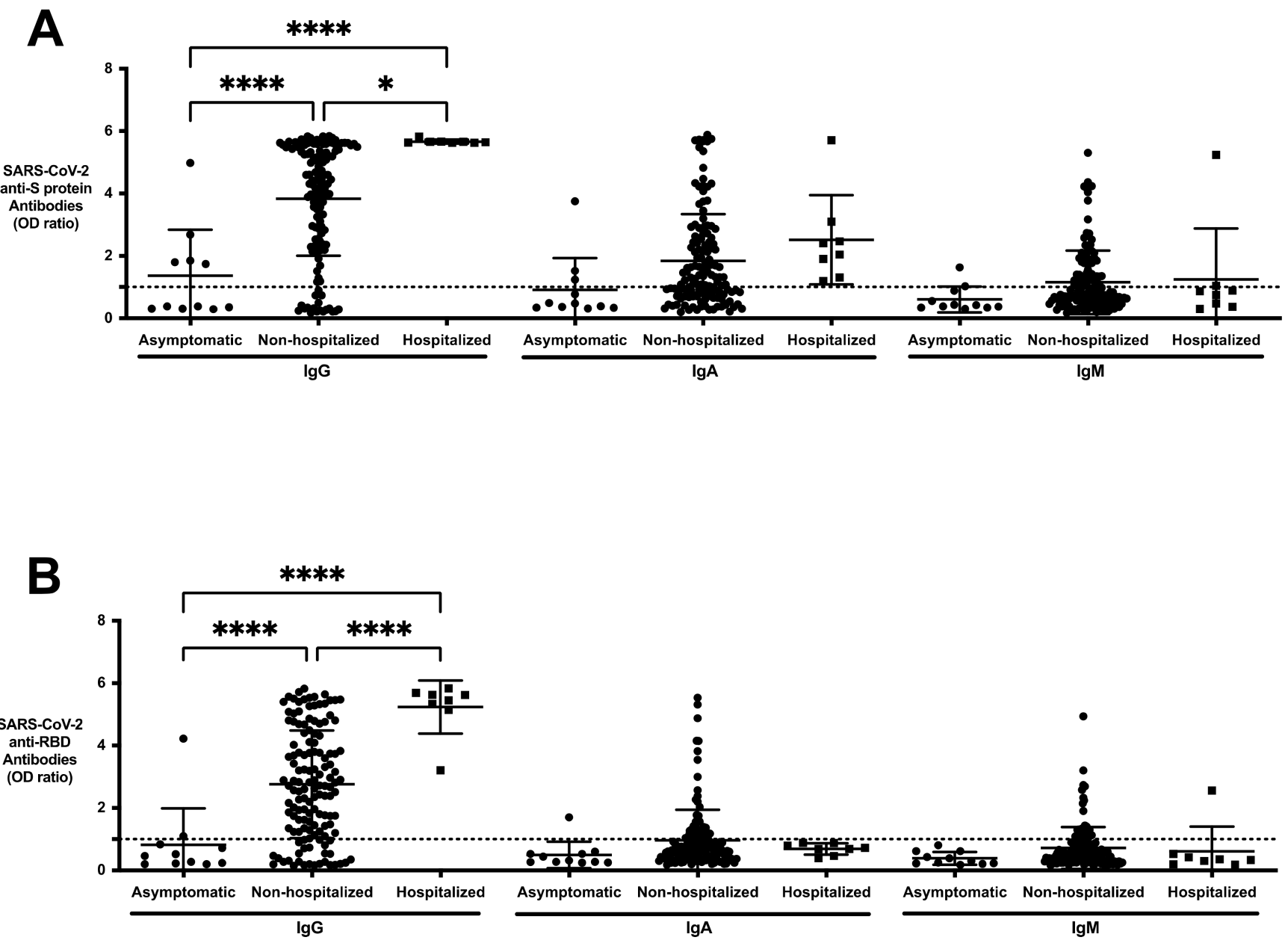

Figure 4. Comparing anti-SARS-CoV-2 IgG, IgA, and IgM responses to S protein and RBD antigens in asymptomatic, non-hospitalized, and hospitalized resolved subjects. (A) Anti-S protein IgG, IgA, IgM, and (B) anti-RBD IgG, IgA, and IgM of the asymptomatic ( $n=11)$, non-hospitalized resolved subjects $(n=134)$ and hospitalized resolved subjects $(n=8)$ were profiled using the SARS-CoV-2 ELISA. Values are shown as a ratio of observed optical density to the determined assay cut-off optical density. All hospitalized subjects had detectable anti-S protein IgG, anti-RBD IgG, and anti-S protein IgA antibodies in their serum. The levels of anti-S protein and anti-RBD IgG (mean $\mathrm{OD}_{405 \mathrm{~nm}}$ ratio) in resolved subjects who were hospitalized were significantly higher than the non-hospitalized resolved population. Values above 1 ratio are considered positive in the SARS-CoV-2 ELISA. ${ }^{*} p<0.05,{ }^{* *} p<0.01,{ }^{* * *} p<0.001,{ }^{* * * *} p<0.0005$.

Of the resolved COVID-19 study participants collected, 11 (7.2\%) were asymptomatic. Six of the $11(54.5 \%)$ asymptomatic subjects did not produce any anti-S protein or anti-RBD antibodies (Figure 4). Six of the asymptomatic subjects were in the category of RT-PCRpositive/antibody-negative with a high $\mathrm{Ct}$ value.

\section{Discussion}

Understanding the characteristics of the SARS-CoV-2 antibodies will inform on its seroprevalence in communities and portions of the COVID-19 immune response. We 
describe initial cross-sectional results of our longitudinal study of quantitative and functional SARS-CoV-2 antibodies in resolved subjects. The expression of IgG, IgA, and IgM antibodies reactive to the immunogenic $S$ protein and the RBD varied based on infection of SARS-CoV-2, severity of the disease, and time delay from onset of symptoms to blood draw. We also observed temporal and functional differences in anti-SARS-CoV-2 antibodies based on Ig classes and antigen.

Antibodies to SARS-CoV-2 were found in 131/153 (85.6\%) subjects who tested positive in the RT-PCR. In 22 of $153(14.4 \%)$ resolved subjects who tested RT-PCR-positive, no antibodies against SARS-CoV-2 were detected, which prompted further investigation using $\mathrm{Ct}$ values. Of 18 samples of whom $\mathrm{Ct}$ values were available, 17 had high $\mathrm{Ct}$ values $(32.29 \pm 4.647$, range $=16.00$ to 37.38 , Figure 1D). The variation in antibody response in RT-PCR-positive subjects may be due to multiple contributing factors including the size of the viral inoculum, the genetic background of patients, and the presence of concomitant pathological conditions [28]. Studies have reported that after COVID-19 infection in some subjects, no antibodies can be detected in circulation either because they have waned quickly, or that their immune response is dependent on T cell responses [29-31]. Another factor is disease severity in the detection of SARS-CoV-2 antibodies. Strong neutralizing antibody responses may require more extensive affinity maturation, which is detected more in COVID-19 patients with severe disease symptoms [28,32,33]. Therefore, it is possible that the inability to detect antibodies in RT-PCR-positive subjects may be due to an infection insufficient of magnitude or durability [34]. Another possibility can be that the RT-PCR-positive/antibody-negative subjects had high Ct values at the limit of detection for the assay and did not actually contract the SARS-CoV-2 virus. One study showed there is reduced probability of cultivable viral cultures from samples with a $\mathrm{Ct}>24$ or when samples are obtained $>8$ days after symptom onset, and another study showed $\mathrm{Ct}$ values above 33-34 were not associated with cell culture viral recovery $[35,36]$. Thus, the developed ELISA for all Ig classes against $\mathrm{S}$ protein and RBD antigens has an increased sensitivity of $97.1 \%$ after removal of these 17 subjects with indeterminate test results from analysis.

Two subjects enrolled in this study were categorized as RT-PCR-negative based on a second RT-PCR test. Their initial RT-PCR test was positive, but retested RT-PCR-negative within 1-2 days after the first result due to the initial test having a high $\mathrm{Ct}$ value positive result without any symptoms or contact history. It is possible that some of the RT-PCRpositive/antibody-negative subjects with high $\mathrm{Ct}$ values, would have tested negative in a repeated RT-PCR test as well. A study showing repeat testing of the same subjects describes $6.8 \%$ of participants who initially test positive, tested negative in a follow-up RT-PCR test [37]. Repeating tests can reduce false-positive results, especially in those who have minimal indicators for having been infected. Another way to distinguish possible false-positive results in the RT-PCR is to use a combination of RT-PCR testing and antibody testing to improve the accuracy of COVID-19 diagnosis. One study utilizing rapid antigen diagnostic tests in combination with IgM/IgG detection, identified more subjects with COVID-19 admitted in an emergency department than when the assays are performed separately [38].

Conversely, SARS-CoV-2 antibodies were detected in three (5.5\%) subjects in the cohort who tested RT-PCR-negative. Detection of SARS-CoV-2 antibodies in these samples may be a result of cross-reactivity of the antibodies with seasonal coronaviruses from previous infections [39,40]. In the pre-COVID-19 samples $(n=520), 11(2.1 \%)$ had crossreactivity to the SARS-CoV-2 antigens. Additionally, one of the three subjects who was RT-PCR-negative and positive for SARS-CoV-2 antibody was tested in the RT-PCR 113 days after initial symptom onset, which is later than the optimal timing since symptom onset for RT-PCR testing, possibly being the reason for a false-negative RT-PCR test. Taking into account the RT-PCR-negative cohort of subjects, we calculated the overall specificity of the in-house ELISA to be $96.7 \%$. 
Antibody kinetics reported previously in SARS-CoV-2 infected subjects suggest that titers of the virus-specific IgG and IgM antibodies increase 21 days post symptom onset [18,41]. However, other studies indicate conflicting evidence on whether IgG and neutralizing antibody levels persist or begin to decline in a high proportion of recovered subjects within 2-3 months after infection [18]. Our study found that IgM positivity was lower than that of IgG after infection $[18,39,42,43]$. Minimal differences were also observed in the percentage of anti-S protein and anti-RBD antibodies present in participants drawn at various times over a three-month period. Furthermore, anti-SARS-CoV-2 antibodies could be found in the circulation of some resolved subjects 200 days post-symptom onset. Resolved subjects who were asymptomatic but RT-PCR-positive, had the lowest titer of SARS-CoV-2 antibodies.

Our study also used whole live SARS-CoV-2 virus in the neutralization assay which was able to determine the functional inhibitory capacity of antibodies against all antigens of SARS-CoV-2. Neutralizing antibody titers have recently been shown to wane fairly rapidly in some studies and levels were found to be variable in recovered subjects $[19,21,44-46]$. The FDA recommends that the titer of neutralizing antibodies in convalescent plasma should be at least $1 / 160$, but a $1 / 80$ titer is acceptable in the absence of a better match for use in convalescent plasma therapy [47]. Most resolved COVID-19 subjects were found to have developed levels of SARS-CoV-2-specific neutralizing antibodies similar to other cross-sectional studies $[19,45,46]$. Neutralizing SARS-CoV-2 antibodies correlated best with a positive anti-RBD IgG $(r=0.5157)$ and anti-S protein IgG antibody $(r=0.6010)$ result. However, at this time we do not know what relevant thresholds of neutralizing antibodies confer protection from infection. Of interest, it has been shown that although Fcdependent effector functions are required for optimal protection, these are often mediated by non-neutralizing antibodies [48]. Neutralization assays are performed with serum, and thus it is not possible to define the relative contribution of each antibody class to neutralizing activity.

This study has limitations. Recall bias of dates and symptoms by the study participants may affect the interpretation of timing of virus detection in relation to symptom onset. For asymptomatic cases, the time when infection was acquired is not known. In conclusion, our study suggests that there is a variable antibody response in resolved subjects and a variable reduction in antibody positivity over time. The negative antibody results found in the SARS-CoV-2 ELISA in RT-PCR-positive samples may suggest a varied immune response that warrants further studies.

Serological assays are important for the study of COVID-19 as they characterize the nature and kinetics of SARS-CoV-2 antibodies and their ability to confer long-term immunity via immunological memory. Although serologic tests cannot be used as the primary diagnostic test, they may also be used to support diagnosis of COVID-19 for persons who are tested later outside the optimal RT-PCR window, and thus provide an additional diagnostic value in verifying results and help monitor and control the spread of COVID-19. The resolved subjects collected for this study are part of a larger longitudinal study that will provide further insight on antibody prevalence over time.

Supplementary Materials: The following are available online at https: / www.mdpi.com/article / 10.3390/v13040697/s1, Figure S1: Optimizing antigen concentration for the SARS-CoV-2 ELISA, Figure S2: Comparing the effect of heat-treatment and Triton X-100 treatment on assay performance, Figure S3: Determining inter-assay variability of the SARS-CoV-2 ELISA, Figure S4: Inhibition of anti-RBD IgG binding using excess RBD in solution, Figure S5: Cross-sectional analysis of IgG, IgA, and IgM responses to $S$ protein and RBD antigens of SARS-CoV-2 in serum, Figure S6: Neutralizing SARS-CoV-2 antibodies against $S$ protein and RBD in IgA, and IgM in resolved and RT-PCR-negative study participants, Table S1: Comparing results from the in-house SARS-CoV-2 ELISA to two commercial assays.

Author Contributions: A.H. carried out the described studies, analyzed data, and wrote the manuscript. D.M.A. designed the research and helped write the manuscript. J.W.S. and A.Z. carried out the described studies, analyzed data, and wrote the manuscript. J.C.M. assisted with experimentation, provided technical assistance, and helped write the manuscript. V.T.C. provided technical 
assistance. H.D.S. and J.C.A. provided technical assistance and materials. Z.C., B.J.H., R.C., N.I., D.M.E.B., M.S.M., and J.G.K. designed the research and helped write the manuscript. I.N. designed the research, interpreted data, and wrote the manuscript. All authors have read and agreed to the published version of the manuscript.

Funding: Funding support for this work was provided by grants from the Ontario Research Fund (ORF), COVID-19 Rapid Research Fund (\#C-191-2426729-NAZY) and by the Canadian Institute of Health Research (CIHR)-COVID-19 Immunity Task Force (CITF; \#VR2-173204) awarded to Dr. Ishac Nazy, and Academic Health Sciences Organization (HAHSO) grant awarded to Dr. Donald M. Arnold (\#HAH-21-02). This work was also supported, in part, by a Weston Family Microbiome Initiative Grant and a CIHR COVID-19 Rapid Response grant to Dr. Matthew S. Miller. Dr. Miller was also supported, in part, by a CIHR New Investigator Award and an Ontario Early Researcher Award. Ali Zhang is supported by a PSI Research Trainee Fellowship and a CIHR Canada Graduate ScholarshipsDoctoral Award. Hannah D. Stacey was supported in part by an Ontario Graduate Scholarship.

Institutional Review Board Statement: This study was approved by the Hamilton Integrated Research Ethics Board (HIREB).

Informed Consent Statement: Informed consent was obtained from all subjects involved in the study.

Data Availability Statement: The data presented in this study are available on request from the corresponding author.

Acknowledgments: We thank Erjona Kruja for her technical assistance.

Conflicts of Interest: The authors declare no conflict of interest.

\section{References}

1. Zhou, P.; Yang, X.L.; Wang, X.G.; Hu, B.; Zhang, L.; Zhang, W.; Si, H.R.; Zhu, Y.; Li, B.; Huang, C.L.; et al. A pneumonia outbreak associated with a new coronavirus of probable bat origin. Nature 2020, 579, 270-273. [CrossRef] [PubMed]

2. He, X.; Lau, E.H.Y.; Wu, P.; Deng, X.; Wang, J.; Hao, X.; Lau, Y.C.; Wong, J.Y.; Guan, Y.; Tan, X.; et al. Temporal dynamics in viral shedding and transmissibility of COVID-19. Nat. Med. 2020, 26, 672-675. [CrossRef] [PubMed]

3. Anderson, R.M.; Heesterbeek, H.; Klinkenberg, D.; Hollingsworth, T.D. How will country-based mitigation measures influence the course of the COVID-19 epidemic? Lancet 2020, 395, 931-934. [CrossRef]

4. Mizumoto, K.; Kagaya, K.; Zarebski, A.; Chowell, G. Estimating the asymptomatic proportion of coronavirus disease 2019 (COVID-19) cases on board the Diamond Princess cruise ship, Yokohama, Japan, 2020. Eurosurveill 2020, 25, 2000180. [CrossRef]

5. Gudbjartsson, D.F.; Helgason, A.; Jonsson, H.; Magnusson, O.T.; Melsted, P.; Norddahl, G.L.; Saemundsdottir, J.; Sigurdsson, A.; Sulem, P.; Agustsdottir, A.B.; et al. Spread of SARS-CoV-2 in the Icelandic Population. N. Engl. J. Med. 2020, 382, 2302-2315. [CrossRef]

6. Tabata, S.; Imai, K.; Kawano, S.; Ikeda, M.; Kodama, T.; Miyoshi, K.; Obinata, H.; Mimura, S.; Kodera, T.; Kitagaki, M.; et al. Clinical characteristics of COVID-19 in 104 people with SARS-CoV-2 infection on the Diamond Princess cruise ship: A retrospective analysis. Lancet Infect. Dis. 2020, 20, 1043-1050. [CrossRef]

7. Verity, R.; Okell, L.C.; Dorigatti, I.; Winskill, P.; Whittaker, C.; Imai, N.; Cuomo-Dannenburg, G.; Thompson, H.; Walker, P.G.T.; $\mathrm{Fu}, \mathrm{H}$.; et al. Estimates of the severity of coronavirus disease 2019: A model-based analysis. Lancet Infect. Dis. 2020, $20,669-677$. [CrossRef]

8. He, J.L.; Luo, L.; Luo, Z.D.; Lyu, J.X.; Ng, M.Y.; Shen, X.P.; Wen, Z. Diagnostic performance between CT and initial real-time RT-PCR for clinically suspected 2019 coronavirus disease (COVID-19) patients outside Wuhan, China. Respir. Med. 2020, 168, 105980. [CrossRef]

9. Sethuraman, N.; Jeremiah, S.S.; Ryo, A. Interpreting Diagnostic Tests for SARS-CoV-2. JAMA 2020, 323, 2249-2251. [CrossRef]

10. Chu, D.K.W.; Pan, Y.; Cheng, S.M.S.; Hui, K.P.Y.; Krishnan, P.; Liu, Y.; Ng, D.Y.M.; Wan, C.K.C.; Yang, P.; Wang, Q.; et al. Molecular Diagnosis of a Novel Coronavirus (2019-nCoV) Causing an Outbreak of Pneumonia. Clin. Chem. 2020, 66, 549-555. [CrossRef]

11. Corman, V.M.; Landt, O.; Kaiser, M.; Molenkamp, R.; Meijer, A.; Chu, D.K.; Bleicker, T.; Brunink, S.; Schneider, J.; Schmidt, M.L.; et al. Detection of 2019 novel coronavirus (2019-nCoV) by real-time RT-PCR. Eurosurveill 2020, 25, 2000045. [CrossRef]

12. Letko, M.; Marzi, A.; Munster, V. Functional assessment of cell entry and receptor usage for SARS-CoV-2 and other lineage B betacoronaviruses. Nat. Microbiol. 2020, 5, 562-569. [CrossRef]

13. Wrapp, D.; Wang, N.; Corbett, K.S.; Goldsmith, J.A.; Hsieh, C.L.; Abiona, O.; Graham, B.S.; McLellan, J.S. Cryo-EM structure of the 2019-nCoV spike in the prefusion conformation. Science 2020, 367, 1260-1263. [CrossRef]

14. Walls, A.C.; Park, Y.J.; Tortorici, M.A.; Wall, A.; McGuire, A.T.; Veesler, D. Structure, Function, and Antigenicity of the SARS-CoV-2 Spike Glycoprotein. Cell 2020, 181, 281-292.e6. [CrossRef]

15. Berry, J.D.; Hay, K.; Rini, J.M.; Yu, M.; Wang, L.; Plummer, F.A.; Corbett, C.R.; Andonov, A. Neutralizing epitopes of the SARS-CoV S-protein cluster independent of repertoire, antigen structure or mAb technology. MAbs 2010, 2, 53-66. [CrossRef] 
16. Amanat, F.; Stadlbauer, D.; Strohmeier, S.; Nguyen, T.H.O.; Chromikova, V.; McMahon, M.; Jiang, K.; Arunkumar, G.A.; Jurczyszak, D.; Polanco, J.; et al. A serological assay to detect SARS-CoV-2 seroconversion in humans. Nat. Med. 2020, 26, 1033-1036. [CrossRef]

17. Gorse, G.J.; Donovan, M.M.; Patel, G.B. Antibodies to coronaviruses are higher in older compared with younger adults and binding antibodies are more sensitive than neutralizing antibodies in identifying coronavirus-associated illnesses. J. Med. Virol. 2020, 92, 512-517. [CrossRef]

18. Long, Q.X.; Liu, B.Z.; Deng, H.J.; Wu, G.C.; Deng, K.; Chen, Y.K.; Liao, P.; Qiu, J.F.; Lin, Y.; Cai, X.F.; et al. Antibody responses to SARS-CoV-2 in patients with COVID-19. Nat. Med. 2020, 26, 845-848. [CrossRef]

19. Luchsinger, L.L.; Ransegnola, B.P.; Jin, D.K.; Muecksch, F.; Weisblum, Y.; Bao, W.; George, P.J.; Rodriguez, M.; Tricoche, N.; Schmidt, F; et al. Serological Assays Estimate Highly Variable SARS-CoV-2 Neutralizing Antibody Activity in Recovered COVID-19 Patients. J. Clin. Microbiol. 2020, 58. [CrossRef]

20. Okba, N.M.A.; Muller, M.A.; Li, W.; Wang, C.; GeurtsvanKessel, C.H.; Corman, V.M.; Lamers, M.M.; Sikkema, R.S.; de Bruin, E.; Chandler, F.D.; et al. Severe Acute Respiratory Syndrome Coronavirus 2-Specific Antibody Responses in Coronavirus Disease Patients. Emerg. Infect. Dis. 2020, 26, 1478-1488. [CrossRef]

21. Prevost, J.; Gasser, R.; Beaudoin-Bussieres, G.; Richard, J.; Duerr, R.; Laumaea, A.; Anand, S.P.; Goyette, G.; Benlarbi, M.; Ding, S.; et al. Cross-Sectional Evaluation of Humoral Responses against SARS-CoV-2 Spike. Cell Rep. Med. 2020, 1, 100126. [CrossRef]

22. Zhao, J.; Yuan, Q.; Wang, H.; Liu, W.; Liao, X.; Su, Y.; Wang, X.; Yuan, J.; Li, T.; Li, J.; et al. Antibody responses to SARS-CoV-2 in patients of novel coronavirus disease 2019. Clin. Infect. Dis. 2020, 71, 2027-2034. [CrossRef]

23. Roost, H.P.; Bachmann, M.F.; Haag, A.; Kalinke, U.; Pliska, V.; Hengartner, H.; Zinkernagel, R.M. Early high-affinity neutralizing anti-viral IgG responses without further overall improvements of affinity. Proc. Natl. Acad. Sci. USA 1995, 92, 1257-1261. [CrossRef]

24. Chen, Z.; Zhang, L.; Qin, C.; Ba, L.; Yi, C.E.; Zhang, F.; Wei, Q.; He, T.; Yu, W.; Yu, J.; et al. Recombinant modified vaccinia virus Ankara expressing the spike glycoprotein of severe acute respiratory syndrome coronavirus induces protective neutralizing antibodies primarily targeting the receptor binding region. J. Virol. 2005, 79, 2678-2688. [CrossRef]

25. Ju, B.; Zhang, Q.; Ge, J.; Wang, R.; Sun, J.; Ge, X.; Yu, J.; Shan, S.; Zhou, B.; Song, S.; et al. Human neutralizing antibodies elicited by SARS-CoV-2 infection. Nature 2020, 584, 115-119. [CrossRef]

26. Stadlbauer, D.; Amanat, F.; Chromikova, V.; Jiang, K.; Strohmeier, S.; Arunkumar, G.A.; Tan, J.; Bhavsar, D.; Capuano, C.; Kirkpatrick, E.; et al. SARS-CoV-2 Seroconversion in Humans: A Detailed Protocol for a Serological Assay, Antigen Production, and Test Setup. Curr. Protoc. Microbiol. 2020, 57, e100. [CrossRef]

27. Seow, J.; Graham, C.; Merrick, B.; Acors, S.; Pickering, S.; Steel, K.J.A.; Hemmings, O.; O’Byrne, A.; Kouphou, N.; Galao, R.P.; et al. Longitudinal observation and decline of neutralizing antibody responses in the three months following SARS-CoV-2 infection in humans. Nat. Microbiol. 2020, 5, 1598-1607. [CrossRef]

28. Chen, X.; Pan, Z.; Yue, S.; Yu, F.; Zhang, J.; Yang, Y.; Li, R.; Liu, B.; Yang, X.; Gao, L.; et al. Disease severity dictates SARS-CoV-2specific neutralizing antibody responses in COVID-19. Signal Transduct. Target. Ther. 2020, 5, 180. [CrossRef]

29. Peng, Y.; Mentzer, A.J.; Liu, G.; Yao, X.; Yin, Z.; Dong, D.; Dejnirattisai, W.; Rostron, T.; Supasa, P.; Liu, C.; et al. Broad and strong memory $\mathrm{CD}^{+}$and $\mathrm{CD}^{+} \mathrm{T}$ cells induced by SARS-CoV-2 in UK convalescent individuals following COVID-19. Nat. Immunol. 2020, 21, 1336-1345. [CrossRef]

30. Le Bert, N.; Tan, A.T.; Kunasegaran, K.; Tham, C.Y.L.; Hafezi, M.; Chia, A.; Chng, M.H.Y.; Lin, M.; Tan, N.; Linster, M.; et al. SARS-CoV-2-specific T cell immunity in cases of COVID-19 and SARS, and uninfected controls. Nature 2020, 584, 457-462. [CrossRef]

31. Grifoni, A.; Weiskopf, D.; Ramirez, S.I.; Mateus, J.; Dan, J.M.; Moderbacher, C.R.; Rawlings, S.A.; Sutherland, A.; Premkumar, L.; Jadi, R.S.; et al. Targets of T Cell Responses to SARS-CoV-2 Coronavirus in Humans with COVID-19 Disease and Unexposed Individuals. Cell 2020, 181, 1489-1501.e15. [CrossRef] [PubMed]

32. Schultheiss, C.; Paschold, L.; Simnica, D.; Mohme, M.; Willscher, E.; von Wenserski, L.; Scholz, R.; Wieters, I.; Dahlke, C.; Tolosa, E.; et al. Next-Generation Sequencing of T and B Cell Receptor Repertoires from COVID-19 Patients Showed Signatures Associated with Severity of Disease. Immunity 2020, 53, 442-455.e4. [CrossRef] [PubMed]

33. Marklund, E.; Leach, S.; Axelsson, H.; Nystrom, K.; Norder, H.; Bemark, M.; Angeletti, D.; Lundgren, A.; Nilsson, S.; Andersson, L.M.; et al. Serum-IgG responses to SARS-CoV-2 after mild and severe COVID-19 infection and analysis of IgG non-responders. PLoS ONE 2020, 15, e0241104. [CrossRef] [PubMed]

34. Zhao, J.; Zhao, J.; Mangalam, A.K.; Channappanavar, R.; Fett, C.; Meyerholz, D.K.; Agnihothram, S.; Baric, R.S.; David, C.S.; Perlman, S. Airway Memory CD4 ${ }^{+}$T Cells Mediate Protective Immunity against Emerging Respiratory Coronaviruses. Immunity 2016, 44, 1379-1391. [CrossRef]

35. Singanayagam, A.; Patel, M.; Charlett, A.; Lopez Bernal, J.; Saliba, V.; Ellis, J.; Ladhani, S.; Zambon, M.; Gopal, R. Duration of infectiousness and correlation with RT-PCR cycle threshold values in cases of COVID-19, England, January to May 2020. Eurosurveill 2020, 25, 2001483. [CrossRef]

36. La Scola, B.; Le Bideau, M.; Andreani, J.; Hoang, V.T.; Grimaldier, C.; Colson, P.; Gautret, P.; Raoult, D. Viral RNA load as determined by cell culture as a management tool for discharge of SARS-CoV-2 patients from infectious disease wards. Eur. J. Clin. Microbiol. Infect. Dis. 2020, 39, 1059-1061. [CrossRef] 
37. Gniazdowski, V.; Morris, C.P.; Wohl, S.; Mehoke, T.; Ramakrishnan, S.; Thielen, P.; Powell, H.; Smith, B.; Armstrong, D.T.; Herrera, M.; et al. Repeat COVID-19 Molecular Testing: Correlation of SARS-CoV-2 Culture with Molecular Assays and Cycle Thresholds. Clin. Infect. Dis. 2020. [CrossRef]

38. Veyrenche, N.; Bollore, K.; Pisoni, A.; Bedin, A.-S.; Mondain, A.-M.; Ducos, J.; Segondy, M.; Montes, B.; Pastor, P.; Morquin, D.; et al. Diagnosis value of SARS-CoV-2 antigen/antibody combined testing using rapid diagnostic tests at hospital admission. $J$. Med. Virol. 2020, 93, 3069-3076. [CrossRef]

39. Adams, E.R.; Ainsworth, M.; Anand, R.; Andersson, M.I.; Auckland, K.; Baillie, J.K.; Barnes, E.; Beer, S.; Bell, J.I.; Berry, T.; et al. Antibody testing for COVID-19: A report from the National COVID Scientific Advisory Panel. Wellcome Open Res. 2020, 5, 139. [CrossRef]

40. Hicks, J.; Klumpp-Thomas, C.; Kalish, H.; Shunmugavel, A.; Mehalko, J.; Denson, J.P.; Snead, K.; Drew, M.; Corbett, K.; Graham, B.; et al. Serologic cross-reactivity of SARS-CoV-2 with endemic and seasonal Betacoronaviruses. J. Clin. Immunol. 2021. [CrossRef]

41. Duan, K.; Liu, B.; Li, C.; Zhang, H.; Yu, T.; Qu, J.; Zhou, M.; Chen, L.; Meng, S.; Hu, Y.; et al. Effectiveness of convalescent plasma therapy in severe COVID-19 patients. Proc. Natl. Acad. Sci. USA 2020, 117, 9490-9496. [CrossRef]

42. Gao, H.X.; Li, Y.N.; Xu, Z.G.; Wang, Y.L.; Wang, H.B.; Cao, J.F.; Yuan, D.Q.; Li, L.; Xu, Y.; Zhang, Z.; et al. Detection of serum immunoglobulin $\mathrm{M}$ and immunoglobulin $\mathrm{G}$ antibodies in 2019 novel coronavirus infected patients from different stages. Chin. Med. J. (Engl.) 2020, 133, 1479-1480. [CrossRef]

43. Pérez-García, F.; Pérez-Tanoira, R.; Romanyk, J.; Arroyo, T.; Gómez-Herruz, P.; Cuadros-González, J. Rapid diagnosis of SARS$\mathrm{CoV}-2$ infection by detecting IgG and IgM antibodies with an immunochromatographic device: a prospective single-center study. medRxiv 2020. [CrossRef]

44. Lee, W.T.; Girardin, R.C.; Dupuis Ii, A.P.; Kulas, K.E.; Payne, A.F.; Wong, S.J.; Arinsburg, S.; Nguyen, F.T.; Mendu, D.R.; Firpo-Betancourt, A.; et al. Neutralizing Antibody Responses in COVID-19 Convalescent Sera. J. Infect. Dis. 2020, 223 , 47-55. [CrossRef]

45. Wu, F.; Liu, M.; Wang, A.; Lu, L.; Wang, Q.; Gu, C.; Chen, J.; Wu, Y.; Xia, S.; Ling, Y.; et al. Evaluating the Association of Clinical Characteristics With Neutralizing Antibody Levels in Patients Who Have Recovered From Mild COVID-19 in Shanghai, China. JAMA Intern. Med. 2020, 180, 1356-1362. [CrossRef]

46. Muecksch, F.; Wise, H.; Batchelor, B.; Squires, M.; Semple, E.; Richardson, C.; McGuire, J.; Clearly, S.; Furrie, E.; Neil, G.; et al. Longitudinal analysis of clinical serology assay performance and neutralising antibody levels in COVID19 convalescents. medRxiv 2020. [CrossRef]

47. (FDA), U.S. Food and Drug Administration. Investigational COVID-19 Convalescent Plasma. Guidance for Industry 2020, (FDA-2020-D-1825). Available online: https:/ / www.fda.gov/vaccines-blood-biologics/investigational-new-drug-ind-or-deviceexemption-ide-process-cber/recommendations-investigational-covid-19-convalescent-plasma (accessed on 1 March 2021).

48. Winkler, E.S.; Gilchuk, P.; Yu, J.; Bailey, A.L.; Chen, R.E.; Chong, Z.; Zost, S.J.; Jang, H.; Huang, Y.; Allen, J.D.; et al. Human neutralizing antibodies against SARS-CoV-2 require intact Fc effector functions for optimal therapeutic protection. Cell 2021, 184, 1804-1820.e16. [CrossRef] 